\title{
Kindergarten - a Universal Right for Children in Norway
}

\author{
Kristin Holte Haug Jan Storø \\ Oslo and Akershus University College of Applied Sciences \\ Norway
}

The article is divided into three parts. In part 1 the Norwegian kindergarten is introduced. We present some facts and the purpose of the kindergarten as it appears in state documents. We also describe a historical backdrop. In part 2 we present some issues crucial to understanding how the relationship between kindergartens and the Norwegian state. Drawing on research, we discuss a number of key concepts. In part 3 we discuss debates in Norway about the content of the kindergarten, how it is to be staffed and related issues about the quality of kindergarten education and care.

Key words: ECEC, kindergarten, Norway, universalism, welfare state

\section{Introduction}

In today's Norwegian society, kindergartens ${ }^{1}$ are regarded as important by most people as well as by the government, politicians, professionals, researchers and organizations.

Correspondence regarding this article should be addressed to Kristin Holte Haug, Associate Professor, Faculty of Education and International studies, Oslo and Akershus University College of Applied Sciences, Norway. Electronic mail may be sent to : Kristin.HolteHaug@hioa.no.

* This article is a revised version of an article with the title "Kindergartens in Norway - From care for the few to an universal right for all children". The original article was published by the Japanese journal Child Research Net (CRN) in 2012. The revision is done in understanding with CRN. This article is the sole responsibility of the co-authors and not of any other organization or person.
In the course of the last four decades, the kindergarten sector has developed from being a possibility for few to a universal right for all children. Both Norwegian and international research show that high quality kindergartens have a positive impact on children's development, and that the impact lasts a lifetime (Ministry of Education and Research, 2013a). The Kindergarten reform is one of the most important and extensive steps taken by the Norwegian welfare state in recent decades. The government's main goal for its kindergarten policy is the provision of available and affordable kindergarten places of high quality. Kindergartens are mandated by the state to provide children with beneficial opportunities for development and activities in close collaboration and understanding with the 
children's parents (ibid). This does not mean, however, that there is consensus in Norwegian society and political parties about kindergartens. On the contrary, the debates are often hotly argued and loaded with values and priorities, ranging from whether parents shall receive cash benefit for not using the kindergarten to questions concerning the kindergarten's content. As we shall point out, today's kindergarten sector faces a number of major challenges. One of the most debated questions in the Norwegian political arena is focused on how children are to be raised. This has led to a sharpened political focus on both kindergartens and schools.

We will present here the important elements of the Norwegian kindergarten system; play, learning, care and formation, historical background, two key policy programs; parental leave and cash for benefit and the research and development work for the Norwegian kindergarten system, in order to give background for, and to understand it. We describe issues connected to professional standards of kindergartens and what research has shown about them. We will also touch upon discussions about kindergartens focused on the dimension of quantity (numbers of kindergartens) versus that of quality (the kindergarten's content and tasks). This latter issue is central to the parliamentary White Paper (No 41, 20082009) that focused exclusively on the quality of kindergartens in Norway. This was followed by a White Paper (No 24, 2012-2013) discussing the government's objectives for future kindergartens.

\section{Norwegian Kindergartens - some key aspects}

Kindergartens in Norway are for children up to the age of 5 years and are integrated into the national educational system. A keystone of Norwegian educational policy is that children and young people have an equal right to education, regardless of where they live, gender, social and cultural background or any special needs. All public education in Norway is free of charge, while kindergartens have parental fees (Ministry of Education and Research, 2011a).

In 2002, 9\% of mothers believed that kindergarten was the best option for their 1 year-olds, while the proportion in 2010 was 18\% (Utdanningsdirektoratet 2013). In 2004 the Government decided that the fee for having children in kindergartens should not exceed a certain sum. ${ }^{2}$

\section{The Kindergarten Act - purpose}

The first Kindergarten Act in Norway was introduced in 1975. The current Kindergarten Act of 2005 provides clearer regulations for the roles and tasks of kindergartens and of kindergarten authorities. These regulations apply, among other things, to how kindergartens are to be staffed and operated. The purpose clause of the Kindergarten Act presented below spells out the social mandate and the basic values that should form the foundation of the kindergartens (Ministry of Education and Research, 2011b:13).

the children's need for care and play, and promote learning and formation as a basis for an allround 
development...[omit]...The children shall be able to develop their creative zest, sense of wonder and need to investigate. They shall learn to take care of themselves, each other and nature.

...[omit]...The Kindergarten shall promote democracy and equality and counteract all forms of discrimination. Amended in Act No.119 of 19 December 2008 (entry into force 1 August 2010 pursuant to decree No. 828 of 18 June 2010)

Kindergarten Act Purpose

\section{Historical Background}

The Norwegian kindergarten's history ${ }^{3}$ begins in the first half of the 19th century with the establishment of asylums for poor children (Norwegian: "barneasyl"). The guiding philosophy of the children's institutions those early charities supported by private sectors was that investments in these children would yield future benefits for society.

Later in the 1840s, crèches (day care center; organization of adults who take care of children in place of their parents) providing childcare for children under 3 years of age, poor children of unmarried mothers were established. These were influenced by developments outside Norway, chiefly in France where the first crèches had been opened in Paris in 1844.

From the mid-19th century, the first kindergartens inspired by the German pedagogue Frederich Fröbel were established with his main idea that the children should be stimulated by motoric and intellectual development. This ideological foundation is still recognized in today's Norwegian kindergarten with its focus on the child, on the importance of childhood and its attention to play and enjoyment as important elements in child development.

In the second half of the 20th century, the development of kindergartens in Norway accelerated along to development and progress of Norwegian welfare state's classic era lasting from the 1920s to the 1970s.

The year 1975 stands as a watershed in Norwegian kindergarten history because it marked the first legal act to regulate kindergartens. This law was required owing to the rapid growth of kindergartens throughout Norway as well as an urgent need to organize a massive number of fragmented regulations. The Kindergarten Act of 1975 launched a new phase for Norwegian kindergartens.

Following 1975, there has been a growing involvement from the welfare state in the development of kindergartens; and this has been accompanied by equally growing public interest in issues involving these institutions. In 1995, another law amending the Act was passed. These changes included the regulation of kindergarten content in the form of a national curriculum, and the introduction of compulsory school for 6-year-olds. The present law was launched in 2005 and in 2010 the mission statement was once again revised. These changes were implemented to the national curriculum in 2011. Notified changes in the legislation relating to 
kindergartens are suggested in the green paper (NOU, 2012:1) and in the White Paper No 24, (2012-2013) on future kindergartens.

On 1 January 2009, the government introduced the legal right guaranteeing each child a place in kindergarten. The aims of this legislation were to secure all children a good start, to pursue social equality, and to take special care on ethnic minorities (Ministry of Education and Research, 2008).

These relatively frequent changes in laws and framework can be considered as an expression of the Norwegian kindergarten's strong position and an acknowledgement of the necessity to adapt the kindergarten's content and tasks to social changes in Norwegian society. Today's kindergarten is a key social institution that is very important for children, parents, communities and work by ensuring greater participation on the labor market by parents - especially women - on short term as well as long term development. The Norwegian kindergarten has a complex and profound social mandate stating its mission as one involving both self-expression and learning for children (Bjerkestrand, 2012).

The Norwegian kindergarten as a child care institution dovetailed neatly with many of the ideals of the Nordic welfare state model; all citizens would enjoy equally high standards of living corresponding to the universal principles of the Nordic social democratic welfare regime (Korsvold, 2013:12). There are four characteristics of this model represented by the goals and operations of the kindergarten in Norway (Korsvold, 2005):

- Equality with social egalitarianism as a goal

- Universalism understood as meaning that all children should be integrated within the same institutional framework

- Independence from the school sector, with focus on play, not on teaching

- The home as a model

\section{Contemporary Kindergartens}

When describing today's kindergarten in Norway, this article focuses on the constant reminder that the best interests of the child should also be an active factor in national planning, kindergarten administration and pedagogical planning.

When describing today's kindergarten in Norway, two other important developmentsparental leave and cash for care - need to be discussed.

\section{Parental Leave and Cash Benefit}

Parental leave for both mothers and fathers after childbirth is seen as an important way of supporting young families. Today, mothers and fathers can receive $100 \%$ of parental benefits for a period of 49 weeks or $80 \%$ for a period of 59 weeks. There are regulations on these benefits. The mother must take her leave at least 3 weeks immediately before birth and at least 14 weeks after birth. In addition to this, the father must take at least 14 weeks (the so-called "daddy quota"), if not, the 
couple cannot claim these 14 weeks. The remainder of the benefits can be shared between the mother and the father. Paternity leave is one of the most important measures to increase the participation by fathers in the upbringing of their children. Extended paternal quota helps to promote this as well as improving equality between parents in the workplace (Ministry of Children, Equality and Social Inclusion, 2013).

In 1998 the Norwegian Parliament enacted legislation providing a cash benefit for families wanting to keep their children at home after the parental leave. It was decided that families with children between 1 and 3 years old who did not place their child in a kindergarten, should receive a monthly sum from the state. This measure has been hotly debated since its proposal by the Christian-Democratic/ Conservative coalition government who argued that it would strengthen the family and parental ability to bring up their children outside institutions.

The last decade has witnessed a number of critical voices about the negative consequences of this benefit - especially for immigrant families. It has been pointed out that it impedes integration of ethnic minorities in Norway in many ways. This involves a number of issues. Prominent among these are the problems created when immigrant mothers stay at home and outside the labor market as well as when their children's Norwegian language competence is hampered by staying home with their non-Norwegian speaking mothers. Many voices including most researchers in the field have proposed that the cash benefit funding instead should be used to enhance quality in kindergartens (Haug \& Koritzinsky, 2011, 2013).

It has also been claimed that the cash benefit impedes gender equality since mothers stay home instead of having paid work. There were findings that; cash benefits meant that Norwegian mothers are slow returning to work after giving birth and that many women work parttime or less than a full work week for a number of years even after the cash benefit period is over (Drange, 2012).

The Labour party/Social Left/Green coalition that took power in 2005 has argued against cash benefits pointing out that children in a modern society need more than what a family can provide for them. The government gradually reduced the cash benefit sum from the state and made the measure less attractive by excluding the parents of 2 years old from receiving it. Today parents of children 13 to 18 months receive NOK 5000 (\$ 803) per month, and the parents of children 19 to 23 months receive NOK 3303 (\$ 530) per month.

In September 1999, 73\% of all parents of the 1-2 years old received cash benefits, and in 2010, the percentage was reduced to 22. Parents of children with backgrounds from Eastern Europe, Asia, Africa and Latin America receive cash benefit more often than parents in the general population(48\% of children aged 1-2 years from these family backgrounds received cash benefit in September 2010, while 22\% of all children (Directorate of Integration and Diversity, 2013; SSB, 2013). It should be noted that it has become less common to 
receive cash benefits in the recent years. One explanation for these changes is that the coverage of kindergartens has increased and made it easier for parents to get a placement for their child. ${ }^{4}$

\section{Suggestions for a New Act}

A public commission assigned with the task of evaluating and proposing amendments to the legislation on kindergartens published a report to the government (NOU, 2012:1) containing a number of important suggestions for a new Kindergarten Act. In the recent debate focusing on White Paper, Number 24 about future kindergartens, the parliament proposed to initiate a comprehensive review of the Kindergarten Act and regulations. Central proposals for the future kindergarten are;

- Strengthening national regulation of the kindergarten sector. The reason for this is that there now exist considerable variation in how kindergartens are being run and staffed. The keywords behind this suggestion are quality, equality and the best interest of the child.

- Strengthening the rights of children. The focus is on securing, by introducing a legal right, the physical and psychosocial environment of the children. The keywords here are also the best interest of the child.

- Strengthening the inspection system. The keywords here are preventing violation of the law and securing the quality of childcare.

- Requiring that every kindergarten should have 1 adult per 3 children under 3 years of age and 1 adult per 6 children for more than 3 years of age. The keyword is sufficient pedagogical staff.

- Strengthening of and increasing staff capacity by a competence strategy for skills and recruitment 2014-2020 (Ministry of Education and Research, 2013b). The keyword is higher level of competence.

- Supporting more research on kindergartens and issues connected to this sector. The keyword is updated knowledge.

\section{From "Preschool Teacher" to "Kindergarten} Teacher"

In Norway, kindergarten teacher education has evolved from short "Fröbelseminars" given in Sweden, Denmark or Germany up through the 1930s to 2 year studies at private institutions for a number of years, and then finally, to a bachelor study program in Norway in 1980 (Furu et al., 2011).

Today, kindergarten teacher education is carried out as 3 year full time or 4 year part time programs on a bachelor degree level. Universities and university colleges in Norway providing kindergarten teacher education are allowed considerable freedom to run pedagogic programs within a national framework and to establish ties to various organizations, e.g. workplace-based early childhood teacher programs.

In 2012, the Ministry of Education and Research established new national regulations and curricula for kindergarten 
teacher education. Compared to previous regulations, a major change introduced was consolidation of 10 different subjects into a smaller number of "knowledge areas". These new regulations organize the academic content of kindergarten teacher education into six knowledge areas. Within each knowledge area, academic subjects, didactics, pedagogy and practice are integrated in terms of content as well as organization. This new form of organizing studies stressed the importance of clearly presenting pedagogic topics to students (Ministry of Education and Research, 2012).

Among other innovations, the new regulations changed the title "preschool teacher" to that of "kindergarten teacher". This can be seen in the light of a political and a professional agreement that the kindergarten as such is an important separate arena for children aged 1-5 and not a site to be regarded solely as a stepping stone and preparation for school.

\section{Research and Development Work}

Individual researchers in Norway earlier tended to confine their investigations to kindergartens and early childhood education. However, this previously rather narrow research field has expanded considerably in recent decades as new topics have emerged and been developed. As a consequence of the growth of the field, research on kindergartens has been recognized as key part of the educational research field. Also the governmental provision that kindergartens should be seen as an important part of childhood education has had a major influence on research and development work.
Markedly increased numbers of kindergartens in Norway have led to major and ongoing efforts to secure and to improve the quality of the work done in and with kindergartens. Two key goals in this respect are equality and high quality in all kindergartens. To further expand research in education research program field, funding for a large project studying the variations of quality in ECEC in Norway and the effects of different quality on children's well-being and social, emotional and cognitive development was launched under the program Norwegian Research towards 2020 (Utdanningdirektorater, 2013). The project entitled Better Provision for Norwegian children in ECEC will deliver results in 2017 (RCN, 2013).

Even though the research field has expanded kindergartens are still underresearched and the knowledge-base needs to be broadened (NOU, 2012:1). Potential research areas include:

- The organization of kindergartens, including economy, staff, ownership, and work quality

- The influence of kindergartens on children's social, emotional, behavioral and motoric functioning as well as their cognitive and mental health

- The stage of childhood between 1 and 3 years of age

- Children's everyday life - in kinder gartens

- Early childhood learning - in its own right and as a preparatory phase for schooling

- Children's participation in the kinder 
garten

- Inclusion and diversity

- Friendships among children

- The use of digital media and digital tools among preschool children

- Transitions from kindergartens to schools

Kindergarten researchers in the Nordic countries have developed an open access publication Nordic Research on Kindergartens ${ }^{5}$ (NBF). A Scandinavian research base www.nb-ecec.no is now functioning as a gateway to new research from the ECEC.

It should be mentioned that some researchers are critical to kindergartens, as well as to research on kindergartens. Beck (2012) calls for studies that compare children in kindergartens with children who do not attend the kindergartens, criticizing Norwegian kindergarten researchers for not using research from countries outside Scandinavia (ibid).

\section{Discussions on Kindergarten Teacher Education in Norway}

In this part, we present two central discussions on kindergartens receiving most media and political attention in today's Norwegian society.

\section{Play, Learning and Formation}

First, as the number of kindergartens has increased, it has been more important to secure the quality of the services they provide children. The issue of quality touches upon a theme which has been much debated during the past 20 years: namely, the role of kindergartens in a lifelong learning perspective. This has led to emphasizing a pedagogic approach to everyday activities in the lives of children.

A number of voices critical of the governmental pedagogic policy for kindergartens have been raised on behalf of the children's need for play freed from the influence of adults having educational goals. Østrem et al. (2009) and Østrem \& Pettersvold (2012) have voiced concerns about the increased focus on documenting and mapping individual children in kindergartens, e.g. assessment of language skills (Østrem et al., 2009:148).

This issue is also a concern for the authorities. The Green Paper (NOU, 2010:8) discusses how to ensure that all children receive a systematic pedagogical program of high quality. This document also raises question about whether the implementation of this provision is sufficient in relation to the requirements of the Kindergarten Act and regulations.

It can be argued that children learn and experience different things from free play as opposed to pedagogically organized activities. Free play is spontaneous and fantasy-driven and provides a range of possibilities for children to experience emotions, relationships as well as their own reactions in "natural situations". Also, this type of play provides children opportunities for developing social and motor skills. In contrast, the more organized forms of play are often led and monitored by adults.

This debate on free play versus organized adult-led educational activities 
concerns the degree of organization of the everyday life in kindergartens. Most people would probably agree that there should be an optimal balance between free play and organized, adult-led activities in the kindergarten.

\section{Staff and Competence}

In this section, we focus on two challenges involving the issue of quality in Norwegian kindergartens related to a nation-wide shortage of kindergarten teachers as well as ratios of trained versus non-trained personnel in the kindergarten.

One major challenge for today's kindergarten sector is the shortage of kindergarten teachers. This is related to the "explosive" growth of kindergartens during the last decade. The growth of kindergarten places coupled with the shared belief in society at large that kindergartens are good for children has led to today's situation where almost all children aged 1 to 5 years in Norway (90\%) have places in daycare institutions.

On the other hand, Norwegian universities and university colleges have not received funds sufficient to keep up with this growth and they have been unable to graduate enough kindergarten teachers to meet these demands ${ }^{6}$. A solution to this problem has been to make an exemption from the law requiring kindergarten teacher education of all pedagogical leaders. Consequently, there are today in Norway over 4,000 nationwide exemptions from this requirement.

In cooperation with educational institutions and local municipalities, the Ministry of Education and Research has tried to deal with this situation by starting a program for workplace-based early childhood teacher education. Workplace-based studies started in 2007 and represent an innovation for gaining a degree at undergraduate and postgraduate level using experiential knowledge gained through working with children as the basis of an individual academic study program. This four year part-time bachelor degree program requires that students work a minimum of $50 \%$ at their kindergarten workplaces during the course of the bachelor program. This effort, along with the standard educational programs, is slowly helping to fill the nationwide kindergarten teacher gap. However, it is legitimate to raise the question whether this program goes too slowly.

The second issue related to the personnel situation is the ratio of pedagogically trained staff versus untrained staff in kindergartens. The normal situation is 1 kindergarten teacher and 2 assistants per group of children. This focus on building competence among the staff is an important issue in relation to the here and now situation of the children and also with regard to the lifelong learning perspective. The Framework Plan states:

As role models, all staff carries a particular responsibility to ensure that the values of the kindergartens are reflected in practice. Reflections around their own values and behavior must form part of their discussions on pedagogy and practice. The kindergartens must systematically consider whether their own practices and the culture of the kindergarten help to promote the values 
that are to form the bedrock of the activities in the kindergartens (Ministry of Education and Research , 2011b:10).

The staffing situation in Norwegian kindergartens has also been discussed in the UNICEF report The child care transition (2008). Norway meets eight of UNICEF's ten criteria, for example, with its length of paid maternity leave, proportion of children above the poverty line and health services (UNICEF, 2008). But in regard to criteria related to caring for young children, Norwegian kindergartens received some negative assessment compared to kindergartens in many other European countries. The Norwegian kindergarten system failed to meet the minimum requirement criteria of having at least $80 \%$ of staff members with basic training in child care (ibid).

\section{Conclusion: Kindergartens - from children's perspective}

This article's main goal was to present the Norwegian kindergarten and to discuss some of the challenges it faces. As we have indicated, there are a number of different perspectives on the role of kindergartens in Norwegian society. We have shown that a societal perspective has been an important concern in the development of kindergartens in Norway. The kindergarten also has had a key role in policies for lifelong learning of the Norwegian welfare state. Moreover, it has been regarded as a crucial factor in the integration into Norwegian society of children and families from ethnic minorities.
Last, but not least, it is important to assess the value of the development of kindergartens from a child's perspective. This is perhaps the single perspective provoking the most hotly debated arguments about the kindergarten and its place in the welfare state. In following the development of kindergartens through the years, we have come to understand that kindergartens have the potential for providing a range of benefits for the child as long as they manage to maintain high quality in their operations. We propose that a child's perspective should include everyday functions that children value such as a safe and sound environment; other children to play with - but also possibilities to be by oneself during the day; positive and encouraging professionals who listen to them and who are truly interested in their well-being; and days long enough to have time to play - but also days short enough to experience family life. All of these perspectives reveal normative positions, and that shows the need for political and professional debate around how the day to day child care should be solved within a certain society.

\section{References}

Balke, E. (1995). Småbarnspedagogikkens historie. Oslo: Universitetsforlaget.

Beck, C. W. (2012, April 27). Barnehageeksperimentet. Kronikk i Klassekampen.

Bjerkestrand, M. (2012). Kor viktig er barnehagen i Noreg? Artikkel på nettstedet Verdens fineste stilling ledig - bli førskolelærer. (Reading date: 
August 22nd 2013).

Directorate of Integration and Diversity. (2013). Fakta om kontantstotte og barnehage. Retrieved from http://www.imdi.no /no/Fakta-og-statistikk/Kontantstotte -og-barnehage/ (Reading date: August $\left.22^{\text {nd }} 2013\right)$.

Drange, N. (2012). Omsorgen for barna $i$ velferdsstaten. (Doctoral dissertation). Universitetet i Stavanger.

Furu, A., Granholt, M., Haug, K. H. \& Spurkland, M. (2011). Student $i$ dag. Førskolelærer $i$ morgen. Bergen: Fagbokforlaget.

Haug, K. H. \& Koritzinsky, T. (2011). Isolert fra fellesskapet. Hovedinnlegg i Dagsavisen 27.mai 2011.

Haug, K. H. \& Koritzinsky, T. (2013). Lite konkrete fra høyresiden. Hovedinnleggi Dagsavisen 10.juli 2013.

Korsvold, T. (2005). For alle barn. Oslo: Abstrakt forlag AS.

Korsvold, T. (2013). Scandinavian Early childhood and consumer culture. E-book. Bergen: Fagbokforlaget.

Nordisk barnehageforskning (NBF) (2013). Retrieved from https://journals.hioa.no/inde x.php/nbf/(Reading date: August 22nd 2013).

Nordic Base of Early Childhood Education and Care (NB-ECEC). Retrieved from http:// www.nb-ecec.no/ (Reading date: August $2^{\text {nd }}$ 2013).

Norwegian Ministry of Children, Equality and Social Inclusion. (2013). Meld. St. 44 (2012-2013). Likestilling kommer ikke av seg selv.

Norwegian Ministry of Education and Research. (2005). Act no. 64 of June 2005 relating to Kindergartens (the
Kindergarten Act).

Norwegian Ministry of Education and Research. (2008). Ot.prp. nr. 52 (20072008). Om lov om endringer $i$ barnehageloven (rett til plass i barnehage).

Norwegian Ministry of Education and Research. (2009). St.meld. nr. 41 (20082009). Kvalitet $i$ barnehagen (White Paper, Quality of Kindergartens in Norway). Retrieved from http://www.regjeringen.no/pages/ 2197014/PDFS/STM200820090041000DD DPDFS.pdfn (Reading date: August 22nd 2013).

Norwegian Ministry of Education and Research. (2011a). Education-from kindergarten to adult education. Retrieved from http://www.regjeringen.no/upload/ KD / Vedlegg/Veiledninger $\% 20$ og $\% 20$ brosjyrer/Education_in_Norway_f-4133e. pdf (Reading date: August 22nd 2013).

Norwegian Ministry of Education and Research (2011b). Framework plan for the Content and Tasks of Kindergartens. Retrieved from http://www.regjeringe n.no/upload/KD/Vedlegg/Barnehag er/engelsk/Framework_Plan_for_the_ Content_and_Tasks_of_Kindergartens _2011.pdf (Reading date: August 22 ${ }^{\text {nd }}$ 2013).

Norwegian Ministry of Education and Research (2012). Nasjonal forskrift om rammeplan for barnehagelærerutdanning (National regulation, Curriculum on Early Childhood Teacher Eucation). Retrieved from http://www.regjerin gen.no/nb/dep/kd/dok/lover_regler /forskrifter/2012/nasjonal-forskriftom -rammeplan-for-barn.html?id=6840 87 (Reading date: August 22nd 2013).

Norwegian Ministry of Education and 
Research (2013a). Meld. St. 24 (20122013). Framtidens barnehage (White Paper, Kindergartens for the Future). Norwegian Ministry of Education and Research (2013b). Kompetanse for framtidens barnehage. Strategi for kompetanse og rekruttering 2014-2020. Retrieved from http://www.regjeringen. no/upload/KD/Vedlegg/Barnehager /kompetansestrategien/6372Barnehage. pdf (Reading date: August 22nd 2013). NOU. (2010:8). Med forskertrang og lekelyst. (Report from Public Commision assessing educational service to children in kindergartens).

NOU. (2012:1) Til barnas beste. (Report from Public Commision suggesting changes in the legislation relating to kindergartens).

Statistics Norway (SSB) (2013). Retrieved from http://www.ssb.no/en/forside;jsessi onid=0F231B052BB77E9B1BE06E3D2A 4AE0CF.kpld-as-prod03 (Reading date: August 22nd 2013).

The Research Council of Norway. (2013) Retrieved from http://www.forsk ningsradet.no/en/Home_page/117731 5753906 (Reading date: August 22 ${ }^{\text {nd }}$ 2013).

UNICEF. (2008) The Child Care Transition. A league table of early childhood education and care in economically advanced countries. Innocenti Report Card 8. Retrieved from http://www.unicef-irc.o rg/publications/507 (Reading date: August $22^{\text {nd }} 2013$ ).

Utdanningsdirektoratet. (2013). Utdanningsspeilet 2013. Tall og analyse av barnehager og grunnopplaring $i$ Norge.
Østrem, S., Bjar, H., Line Rønning, L. F., Hogsnes, H. D., Jansen, T. T., Nordtømme, S. \& Tholin, K. R. (2009). Alle teller mer. En evaluering av hoordan Rammeplan for barnehagens innhold og oppgaver blir innført, brukt og erfart. Rapport nr. 1/2009. Tønsberg, Høgskolen i Vestfold.

Østrem, S. \& Pettersvold, M. (2012). Mestrer, mestrer ikke; jakten på det normale barnet. Oslo: Res Publica.

\section{Notes}

${ }^{1}$ The Norwegian term for institutions providing early childhood education and care for children between 0-5 years of age, is barnehage, directly translated to kindergarten.

2 This fee is set in the national budget every year and is at present fixed at NOK 2,330 (USD 374). Parents with more than one child benefit from a fee reduction of minimum $30 \%$ for the second child and minimum $50 \%$ for the third or following children. The municipalities are in addition obliged to ensure that low-income families have places at reduced fees or free of charge.

${ }^{3}$ The historic backdrop is based on Balke (1995); Furu, et al. (2011); Korsvold (2005).

4 The Conservative coalition government who took over in September 2013 has proposed changes concerning both parental leave and the cash benefit from 2014.

5 The articles in this publication are written either in English, or in a Nordic language with an abstract in English.

${ }^{6}$ It should be mentioned that the lack of kindergarten teachers has been a problem for the Norwegian ECEC-sector for many decades. Other explanations for the lack of trained personnel are apostasy from the profession (approx. 50\% of trained kindergarten teachers working outside the kindergarten), lack of recruitment and higher education institutions' training capacity. 


\section{Appendix}

\section{Facts about Norwegian Kindergartens}

- Kindergartens (Norwegian. "barnehager") are pedagogical institutions that provide early childhood education and care for children between (0)1-5 years of age.

- Children in kindergarten: 286,147

- $\quad$ Coverage for children aged from 1 to 5 Years: Approx. 90\% (1-2 Years: 80\%; 3-5 Years: 97\%).

- $\quad$ Average attendance per week: 35 hours

- $\quad$ Number of kindergartens: 6, 273

- $\quad$ Ownership: $53 \%$ private, $47 \%$ public

- $\quad$ Kindergarten employees: 91,255 people (73,228man-years)

- $\quad$ Proportion of employees with kindergarten teacher education: Approx. 33 \% (1 of 3)

- $\quad$ Proportion of male employees: Approx.10 \%

- $\quad$ Average monthly rate for a full-time place: NOK 2,297 (households with a gross annual income of NOK 500,000)

- $\quad$ Maximum monthly rate: NOK 3,330

Source: Statistics Norway (SSB) (2013).

\section{National Kindergarten Documents - Regulatory and Policy}

- $\quad$ Kindergarten Act No. 64 of June 2005 relating to kindergartens. Enacted 1. January 2006.

- Framework Plan for the Content and Tasks of kindergartens (2011). Norwegian Ministry of Education and Research.

- Norwegian Ministry of Education and Research. (2012). Nasjonal forskrift om rammeplan for barnehagelærerutdanning (National regulation, Curriculum for Early Childhood Teacher Education).

- $\quad$ Norwegian Ministry of Education and Research. (2009). White Paper, No. 41 (20082009). Quality of Kindergartens.

- Norwegian Ministry of Education and Research (2013). White Paper, No 24 (20122013). Framtidens barnehage (Kindergartens for the future).

- $\quad$ Norwegian Ministry of Education 2010:8 Med forskertrang og lekelyst (Report from public commision discussing pedagogical provision for all pre-school children)

- $\quad$ Norwegian Ministry of Education 2012:1 Til barnas beste. Ny lovgivning for barnehagene (Report from public commision suggesting changes in the legislation relating to kindergartens). 